IBAD Sosyal Bilimler Dergisi

IBAD Journal of Social Sciences

dergipark.org.tr/ibad

IBAD, 2021; (10): 340-353

DOI: $10.21733 /$ ibad. 872114

Özgün Araştırma / Original Article

\title{
Örgüitsel Vatandaşlık Duygusal Zekâ ve İş-Aile Yayılımı Arasındaki İlişkilerin İncelenmesi
}

\section{Examining the Relationships Between Organizational Citizenship Behaviours Emotional Intelligence and Work-Family Spillover}

\author{
Ali Eryılmaz ${ }^{1^{*}}$ \\ Ahmet Cevdet Açıkgöz ${ }^{2}$ \\ Emre Er ${ }^{3 *}$ \\ * Sorumlu yazar \\ Corresponding author \\ ${ }^{1}$ Prof.Dr., Yıldız Teknik Üniversitesi Türkiye \\ Prof.Dr., Yıldız Technical University, Turkey \\ aeryilmz@yildiz.edu.tr
}

ORCID ID 0000-0001-9301-5946

${ }^{2}$ Öğretmen, MEB, Türkiye

Teacher, MoNE, Turkey

cevdetacikgoz@gmail.com

ORCID ID 0000-0001-9513-2070

${ }^{3}$ Dr. Öğretim Üyesi, Yıldız Teknik Üniversitesi Türkiye Assist. Prof. Dr., Yıldız Technical University, Turkey emreer@yildiz.edu.tr

ORCID ID 0000-0002-9084-6768

Makale geliş tarihi / First received : 01.02.2021

Makale kabul tarihi / Accepted : 31.03 .2021

Bilgilendirme / Acknowledgement:

Yazarllar aşağıdaki billgillendirmeleri yapmaktadırlar:

1- Araştırmacıların tümü makalenin tamamına ortak katkı sağlamıştır.

2- Makalenin yazarları arasında çıkar çatışması bulunmamaktadır.

2- Mevcut çalışmaya ilişkin Yıldız Teknik Üniversitesi Akademik Etik Kurulunun 24/12/2020 tarih ve 2020/11 sayılı kararı ile alınan Etik Kurul izni bulunmaktadır.

3- Bu makalede araştırma ve yayın etiğine uyulmuştur.

This article was checked by Turnitin. Similarity Index 10\%

\section{Atıf bilgisi / Citation:}

Eryılmaz, A., Açıkgöz, A.C., Er, E. (2021). Örgütsel vatandaşlık duygusal zekâ ve iş-aile yayılımı arasındaki ilişkilerin incelenmesi. IBAD Sosyal Bilimler Dergisi, (10), 340-353. 


\section{Öz}

$\mathrm{Bu}$ çalışmanın amacı çağrı merkezi çalışanlarının örgütsel vatandaşlık davranışlarına duygusal zekâ ve iş-aile yayılımlarının etkisinin incelenmesidir. Çalışma ilişkisel tarama olarak tasarlamış ve 200 çalışan araştırmaya dâhil edilmiştir. Araştırmanın verilerinin toplanması amacıyla "Örgütsel Vatandaşlık Davranışı Ölçeği", "Duygusal Zekâ Ölçeğii" ve "İş-Aile Yayılımı Ölçeği" kullanılmıştır. Araştırma verileri IBM SPSS 22 paket programı kullanılarak analiz edilmiştir. Araştırma sonuçlarına göre örgütsel vatandaşlık ile duygusal zekâ, pozitif iş-aile ve aile iş yayılımı arasında olumlu, negatif aile-iş, iş-aile yayılımı arasında olumsuz ilişki mevcuttur. Araştırmada kadın katılımcıların duygusal zekâ ve negatif iş-aile yayılımı algıları erkek katılımcılara göre daha yüksek bulunmuştur. Örgütsel vatandaşlığın yordanma düzeyinin anlaşılmasına ilişkin çoklu regresyon analizi gerçekleştirilmiştir. Bunun sonucunda duygusal zekâ ve pozitif iş aile yayılımının örgütsel vatandaşlığın olumlu yordayıcıları oldukları anlaşılmıştır. Çalışma sonuçlarına dayalı olarak çalışanların örgütsel vatandaşlık davranışlarında duygusal zekâ düzeyleri ve iş-aile dengelerinin daha detaylı anlaşılmasına ilişkin önerilerde bulunulmuştur.

\section{Anahtar Kelimeler}

Örgütsel vatandaşlık, Duygusal zekâ, İş-aile yayılımı, Aile -iş yayılımı.

\section{ABSTRACT}

The aim of this study is to examine the effects of emotional intelligence and work-family spill over on the organizational citizenship behaviors of call center employees. The study is designed as a relational screening and 200 employees were included in the study. "Organizational Citizenship Behavior Scale", "Emotional Intelligence Scale" and "Work-Family Distribution Scale" were used to collect the data of the study. Research data were analyzed using IBM SPSS 22 package program. According to the results of the research, there is a positive relationship between organizational citizenship and emotional intelligence, positive work-family and familywork spill over, and a negative relationship between family-work, work-family spill over. In the study, female participants' perceptions of emotional intelligence and negative work-family spill over were found to be higher than male participants. Multiple regression analysis was conducted to understand the predictive level of organizational citizenship. As a result, it has been understood that emotional intelligence and positive workfamily spill over are positive predictors of organizational citizenship. Based on the results of the study, suggestions were made for a more detailed understanding of emotional intelligence levels and work-family balances in employees' organizational citizenship behaviors.

\section{Keywords}

Organizational citizenship, Emotional intelligence, Workfamily spillover, Family-work spillover 


\section{GíRiş}

Çalışanların kendilerinden beklenilen rol ve sorumluluklardan daha fazlasını yerine getirmeleri örgütsel süreçlerin iyileştirilmesi bakımından oldukça önemlidir. Örgütlerde beklenilen hedeflerinin gerçekleştirilebilmesi amacıyla çalışanların sergilediği çaba literatürde örgütsel vatandaşlık davranışı olarak ifade edilmektedir (Sezgin, 2005). Örgütsel vatandaşlık davranışına ilişkin literatürde en sık karşılaşılan tanım Dennis W. Organ tarafından yapılmıştır. Organ'a (1988, s. 4) göre örgütsel vatandaşlık davranışı, çalışma ortamında birey için belirlenen standartlar ve iş tanımları dışında, isteğe bağlı olarak gerçekleştirilen ve organizasyonun etkili bir biçimde işlemesini sağlayan davranışlardır. Örgütsel vatandaşlık davranışları çalışanlar arasındaki işbirliğini artırması ve bireysel sorumluk almayı desteklemesi bakımından okul gelişimine katkı sağlama potansiyeli taşımaktadır. Bununla birlikte işe yeni başlayan çalışanların sosyalleşme sürecine destek olma, iş yükünün artması durumunda diğer çalışanlara yardımcı olma, örgütsel süreçlerin iyileştirilmesi amacıyla yenilikçi fikir geliştirme, işe gelemeyen veya performansı düşen çalışma arkadaşlarına yardımcı olma çalışanların örgütsel vatandaşlık davranışlarına örnek olarak gösterilebilir (Kelloway, Loughlin, Barling ve Nault, 2002, s. 150).

Örgütsel vatandaşlığın temel varsayımları incelendiğinde, örgüte yönelik katkı sağlanması, örgütsel süreçlerin kolaylaşmasının sağlanması ve diğer çalışanların da benzer davranışlar sergilemeye teşvik etmenin önemli olduğu görülmektedir (Bolino, Turnley ve Niehoff, 2004). Örneğin deneyimli çalışanların göreve yeni başlayanlara destek olması, örgütsel ve yönetsel süreçlerin iyileşmesinin yanında yeni çalışanların örgüte uyumu ve mesleki gelişim süreçlerini de olumlu etkilemektedir. Bununla birlikte çalışanlar arasında yüksek düzeylerde yardım etme ve işbirliği davranışının grup uyumunu artıracağı, örgütü çalışmak için daha cazip bir yer haline getireceği ve örgütsel verimliliği artıracağı tahmin edilmektedir (George ve Bettenhausen, 1990; Podsakoff, Ahearne ve MacKenzie 1997). Örgütsel vatandaşlığın bireysel ve örgütsel olarak olumlu çıktıları baskın olduğundan literatürde genellikle sözkonusu çıtıların açıklanmaya çalışıldığı görülmektedir. Ancak çalışanların örgütsel vatandaşlık davranışları sergilemelerinin bazı olumsuz sonuçları da söz konusudur. Çalışanların iş yerinde fazladan rol ve sorumluluk almaları diğer arkadaşlarının kendileri hakkında olumsuz algılara sahip olmalarına neden olabilir. Bununla birlikte bazı çalışanların örgütsel vatandaşlık düzeyinin yüksek olmasında iş-aile dengesinin kurulamaması ve bireysel olarak yaşanan yalnızlığın giderilmesinin amaçlanmasının etkili olabileceği ifade edilmektedir (Bolino, Turnley ve Niehoff, 2004, s. 234).

Örgütsel vatandaşlık davranışı çalışanların iş yaşantılarını birçok boyutuyla etkilemesi bakımından önemli bir kavram olarak görülmektedir. İşte geçirilen yaşantılar çalışanların yaşamlarını farklı şekillerde etkileyebilmektedir. Çalışanların iş arkadaşlarıyla ilişkilerinin iş ve aile hayatlarını etkilediği söylenebilir. İş yerinde özellikle çalışanların ilişkileri yönetme yeterlikleri ile duygularını yönetme düzeyleri arasında ilişki kurmak mümkündür. Çalışanların duygularını tanıması, kendilerini motive edebilmesi veya duygularını doğru ifade edebilmesi duygusal zekâ kavramıla açıklanmaktadır (Arslan, 2019). Duygusal zekâ, duyguları algılama ve ifade etme, düşünce düzeyindeki duyguları özümseme, duyguyla anlama ve akıl yürütmeye ek olarak kendisinin ve başkalarının sahip olduğu duyguları düzenleyebilme yeteneği olarak tanımlamıştır (Mayer, Salovey ve Caruso, 2000). Baron (1997) ise duygusal zekâyı, bireyin çevresel talep ve baskılarla etkili bir şekilde başa çıkabilme 
özelliğini kapsayan duygusal, kişisel, sosyal becerilerin bütünü olarak ifade etmiştir. 1995 yılında Daniel Goleman'ın "Duygusal Zekâ" kitabını yayınlaması ile kavrama yönelik ilgi artmış, birçok araştırmada tartışılmaya başlanmış ve konu kamuoyunun gündemine girmiştir (Yeşilyaprak, 2001). Goleman'a göre (1995), zekâ bilişsel ve duygusal zekâ olarak ikiye ayrılmakta olup, iki zekânın birbirleriyle etkileşimde bulunmadan gerçek anlamda etkili olamamaktadır. Ayrıca yazara göre duygusal zekâyı; duyguları anlayabilme, tanıyabilme, böylece doğru kararlar alabilme, olumsuz duygularla başa çıkabilme, harekete geçebilme ve dürtülerine hâkim olabilme olarak tanımlamak mümkündür.

Duygusal zekânın iş hayatındaki etkileri farklılık göstermektedir. Örneğin bir çalışan eğer ortaya çıkan çatışmayı yönetmek amacıyla gereken duygusal öz-yönetim becerilerinden yoksunsa saldırgan bireylerle özdeşleşerek iletişimi yıkıcı boyutlara götürecek ve ortak noktada uzlaşma olasılığını ortadan kaldıracaktır (Bachman, Stein, Campbell ve Sitarenios, 2000). Olumlu duygu durumları çalışanlar açısından örgütsel yaşamda bireylerarası sorunların ve karmaşık problemlerin çözülmesinde önemli bir yer tutmaktadır. Duygusal zekâsı yüksek olan çalışanların diğerlerine göre farklı koşullara uyum sağlama yeteneklerinin yüksek olduğu söylenebilir. Bu durum duygusal zekâsı yüksek çalışanların iş stresiyle, iş veya aile hayatında yaşadıkları değişikliklerle karşılaşırken diğer bireylerle benzer zorluklarla karşılaşsalar da kendilerine göre bu sorunları çözme yeterliklerinin yüksek olduğu şeklinde yorumlanabilir (Carmeli, 2003, s. 797).

Duygusal zekâ ile ilgili yapılan araştırmalar, bireylerin iş ve aile yaşantılarında, özellikle karşı tarafın ilişkilerini anlama ve ilişkileri yönetme bakımından önemli sayılmaktadır. Duygusal zeka ile liderlik davranışları (Delice ve Günbeyi, 2013), yöneticilerin problem çözme yöntemleri (Akın, 2004), örgüt performansı (Doğan ve Demiral, 2007), iş doyumu ve performansı (Sy, Tram, ve O'Hara, 2006), örgütsel bağlılık (Nikolaou ve Tsaousis, 2002); ailede birlik ve beraberlik (Özabacı, 2006), aile içi etkili iletişim (İsmen, 2004) ve iş-aile rolleri çatışmaları (Akintayo, 2010) arasındaki ilişkileri inceleyen araştırmalar mevcuttur.

Bireyin iş ve aile yaşamı arasındaki etkileşim ve bu iki alanda sahip olduğu roller hem iş hayatında hem de genel yaşamında önemli bir etkiye sahiptir (Polatcı ve Keser, 2017). Çalışanların iş ve aile yaşantıları karşılıklı olarak birbirini etkileme potansiyeli taşımaktadır. Bununla birlikte literatürde iş yaşamının aileyi etkileme gücünün, ailenin işi etkileme gücüne göre daha yüksek düzeyde olacağını öne süren teoriler mevcuttur (Pleck, 1977). Aile yaşantısı iyi olan bir bireyin bu durumu iş yaşantısına transfer etmesi veya iş yaşantısında sorunlar yaşayan bireyin ise bu durumu ailesi ile ilişkilendirmesi olasıdır. Sonuç olarak iş hayatında yaşananların aile yaşantılarını, aile hayatında yaşananların ise iş yaşantılarını etkilemesi mümkündür. Literatürde bu durum; iş-aile yayılımı kavramıyla açıklanmaktadır (Polatcı, 2014). Buna göre bireyin her iki yaşam alanının birbiri üzerinde etkili olması beklenmektedir. İşte yaşananlar aile hayatına ya da tam tersi şekilde, ailede yaşananlar iş hayatına getirilebilir (Hanson, Hammer ve Colton, 2006).

İş-aile yayılımı ile ilgili öncü araştırmalarda çalışanlarla yarı yapılandırılmış görüşmeler yapılmış ve çoğunun ailelerinde yaşadıklarının iş yaşantılarını etkilediği sonucu ortaya çıkmıştır (Crouter, 1984). Ayrıca araştırmada evden işe pozitif ve negatif etki incelendiğinde, küçük yaşta çocuğu olan kadınların, daha büyük yaşta çocuğu olanlara göre iş-aile etkileşiminin daha yüksek düzeyde yayılma gösterdikleri ifade edilmiştir. Buna göre 
çocukların yaşları ile iş-aile yayılımına etkisi arasında ilişki olduğu söylenebilir. Bazı araştırmacılar iş-aile yayılımını pozitif ve negatif boyutları olan bir kavram olarak ele almıştır. Pozitif iş-aile yayılımı, ailenin işi desteklemesi, işi kolaylaştırması ve geliştirmesi olarak ele alınırken; negatif iş-aile yayılımı çalışılan işi zorlaştıran, problemli ve rahatsız edici bir duruma sokan durumlar olarak tanımlanmaktadır (Kirchmeyer, 1993). Pozitif iş-aile yayılımı, iş hayatından edinilen olumlu etki, değer, beceri ve davranışların aile hayatına yansımasıdır. Ailede yaşananların, iş yaşantılarını ve zorluklar karşısında mücadele ederek başarıya ulaşma olarak tanımlanan psikolojik sermayeyi etkilemesi (Polatcı, 2011) nedeniyle çalışanların mesleki performanslarında belirleyici role sahiptir.

Örgütsel vatandaşlık üzerine yapılan araştırmalarda katılımcıların demografik değişkenlerinin yanı sıra liderlik, örgüt kültürü, bireysel iş performansı ve örgütsel adalet gibi değişkenlerin sıklıkla kullanıldığı bilinmektedir örgütsel vatandaşlık davranışının iş performansını etkilemesi (Çelik ve Çıra, 2013; Er, Akyol ve Koşar, 2019; Williams ve Anderson, 1991). Söz konusu çalışmalarda genellikle örgütsel vatandaşlık davranışının sonucunda ortaya çıkan bireysel ve örgütsel değişkenlere odaklanıldığı görülmektedir. Başka bir anlatımla birçok çalışmada örgütsel vatandaşlık bağımsız değişken olarak ele alınmıştır. Literatürde sınırlı sayıdaki çalışmada örgütsel vatandaşlığın açıklanmasına yönelik araştırma yer almaktadır (Koşar ve Yalçınkaya, 2013; Yıldırım ve Kara, 2018).

Örgütsel vatandaşlık ile ilgili çalışmalarda genellikle örgütsel değişkenler ile vatandaşlık davranışı arasındaki ilişkilerin incelendiği görülmektedir. Mevcut araştırmada çalışanların bireysel özelliklerinin açıklayıcısı olarak duygusal zekâ ve aile ile iş yaşamları arasındaki geçişkenliğin incelenmesi amacıyla iş-aile yayılımı kavramları kullanılmıştır. Bu bağlamda çalışmanın örgütsel vatandaşlığın bireysel değişkenlerle ve örgüt dışı etmenlerle potansiyel ilişkisinin anlaşılması bakımından da önem taşımaktadır.

Mevcut araştırmada örgütsel vatandaşlığın bireysel değişkenler olarak duygusal zekâ ve iş-aile yayılımı ile ilişkisi incelenmiştir. Literatürde örgütsel vatandaşlığın ortaya çıkmasında etkili olan bireysel ve örgütsel değişkenlerin incelendiği çalışmaların sınırlı olması ve eğitim yönetimi alanında duygusal zekâ ve iş-aile yayılımı kavramları ile ilgili çalışmaların sınırlı olması nedeniyle mevcut çalışma ile literatüre katkı yapılması amaçlanmıştır.

$\mathrm{Bu}$ araştırmada çalışanların örgütsel vatandaşlık, duygusal zekâ ve iş-aile yayılımı algıları arasındaki ilişkilerin belirlenmesi amaçlanmıştır. Bu amaç doğrultusunda aşağıdaki sorulara cevap aranmıştır.

1) Katılımcıların, örgütsel vatandaşlık, duygusal zekâ ve iş-aile yayılımı düzeyleri nedir?

2) Örgütsel vatandaşlık, duygusal zekâ ve iş-aile yayılımı düzeyleri arasında ilişki var mıdır?

2) Duygusal zekâ ve iş-aile yayılımı örgütsel vatandaşlığın anlamlı yordayıcıları mıdır?

\section{YÖNTEM}

\section{Araştırma Modeli}

Bu çalışma, ilişkisel tarama modeli kullanılarak gerçekleştirilmiştir. İlişkisel tarama iki veya daha çok değişken arasındaki birlikte değişimin varlığını ve derecesini belirlemeyi amaçlayan araştırma modelidir (Karasar, 2010). Çalışmanın amacı örgütsel vatandaşlık davranışı, duygusal zekâ ve iş-aile yayılımı arasındaki ilişkilerin incelenmesidir. Çalışma 
kapsamında katılımcıların duygusal zekâ ve iş-aile yayılımı düzeylerinin örgütsel vatandaşlık üzerindeki yordayıcılıkları incelenmiştir. Araştırmanın bağımlı değişkeni örgütsel vatandaşlık, bağımsız değişkenleri duygusal zekâ ve iş-aile yayılımıdır. Çalışmada, örgütsel vatandaşlık, duygusal zekâ ve iş-aile yayılımı arasındaki ilişkilerin incelenmesi amacıyla Pearson Momentler Çarpımı Korelasyon Katsayısı, bağımsız değişkenlerin bağımlı değişken üzerindeki yordayıcılığını belirlemek amacıyla basit doğrusal regresyon analizi kullanılmıştır.

\section{Evren ve Örneklem}

$\mathrm{Bu}$ araştırmanın katılımcları amaçlı örnekleme yöntemiyle belirlenmiştir. Amaçlı örnekleme, araştırmanın amaçları doğrultusunda, evrenin temsilci örneğini almak yerine, amaçlı olarak bir kesimi örnek olarak almaktır (Sencer, 1989, s 386). Çalışma, 2019 yılında özel bir çağrı merkezinde çalışan 18-45 yaşları arasında 106 erkek (\%53) ve 94 kadın (47) çalışan olmak üzere toplam 200 kişi ile yürütülmüştür. Çalışma grubunda yer alan çalışanların yaş ortalaması 27,36 ve standart sapması 4,57' dir. Mesleki deneyim açısından 1-3 yıl arasında 69 (\% 34.5), 4-6 yıl arasında 84 (\%42), 7 yıl ve üzerinde 47 kişi (\%23.5) yer almaktadır. Eğitim düzeyi bakımından katılımcıların yarısına yakını lisans mezunu (\%48), üçte bire yakını önlisans mezunu (\%27) ve dörtte biri lise mezunu (\%25) olduğunu ifade etmiştir.

Çalışmaya ilişkin Yıldız Teknik Üniversitesi Akademik Etik Kurulunun 24/12/2020 tarih ve 2020/11 sayılı kararı ile alınan Etik Kurul izni bulunmaktadır.

\section{Veri Toplama Araçları}

$\mathrm{Bu}$ araştırma kapsamında kullanılan ve iki bölümden oluşan anket formu ve araştırmada kullanılan ölçeklerin psikometrik özelliklerine ait bilgiler aşağıda yer almaktadır.

Örgütsel Vatandaşlık Davranışı Ölçeği: Williams ve Anderson (1991) tarafından geliştirilen ölçeğin Türkçeye uyarlaması Basım ve Şeşen (2006) tarafından yapılmıştır. 6'lı Likert tipinde olan ölçek, 19 maddeden oluşmakta ve 1 (hiçbir zaman) ile 6 (her zaman) arasında puanlanmaktadır. Ölçekten alınan yüksek puanlar örgütsel vatandaşlık davranışının da yüksek olduğu anlamına gelmektedir. Ölçeğin tamamı için iç tutarlılık katsayısı .89 olarak bulunmuştur. Uygulanan örneklem grubunda ölçeğin bütünü için Cronbach's Alpha iç tutarlılık katsayısı .73 olarak bulunmuştur.

Duygusal Zekâ Ölçeği: Araştırmada, Schutte, Malouff, Hall, Haggerty, Cooper, Golden ve Dornheim (1998) tarafından geliştirilen ve Austin, Saklofske, Huang ve McKenney tarafından 2004 yılında revize edilen Schutte Duygusal Zekâ Ölçeği kullanılmıştır. Bu ölçek Tatar, Tok ve Saltukoğlu (2011) tarafından Türkçeye uyarlanmıştır. Ölçek, 41 maddeden oluşmaktadır. Yapılan geçerlik ve güvenirlik çalışmalarında ölçeğin bütünü için Cronbach's Alpha iç tutarlılık katsayısı .82 , alt ölçekler için ise $.75, .39$ ve .76 olarak tespit edilmiştir. Ölçeğin testtekrar test güvenirlik katsayısını belirlemek amacıyla yapılan Pearson Bağıntı Analizi sonuçlarına göre ölçek toplam puanı için bir hafta aralıklı iki uygulamanın sonucu $r=.49$; iki hafta aralıklı iki uygulamanın sonucu $r=.56$ olarak bulunmuştur. Uygulanan örneklem grubunda ölçeğin bütünü için Cronbach's Alpha iç tutarlılık katsayısı .78 olarak bulunmuştur.

İş-Aile Yayılımı Ölçeği: Grzywacz ve Marks (2000) tarafından geliştirilen ölçek Polatcı (2014) tarafından Türkçe 'ye uyarlanmıştır. Beşli Likert tipinde geliştirilen bu ölçek, 12 madde ve 4 boyuttan oluşmaktadır. Bu alt boyutlar; pozitif iş-aile yayılımı, negatif iş-aile yayılımı, pozitif 
aile-iş yayılımı ve negatif aile-iş yayılımıdır. Ölçeğin iç tutarlılığ1 pozitif ve negatif aile-iş yayılımı için sırasıyla, .70 ve .80 ; pozitif ve negatif iş-aile yayılımı için ise .73 ve .83 olarak bulunmuştur. Güvenirlik için hesaplanan Cronbach's Alpha iç tutarlılık katsayısı alt boyutlar için .70 ile .82 arasındadır. Uygulanan örneklem grubunda ölçeğin bütünü için Cronbach's Alpha iç tutarlılık katsayısı .76 olarak bulunmuştur.

\section{Verilerin Toplanması ve Analizi}

Veri analizi yapılırken IBM SPSS 22 paket programı kullanılmıştır. Araştırmanın amacı kapsamında duygusal zekâ ile örgütsel vatandaşlık davranışı arasındaki ilişkiyi belirleyebilmek için çoklu regresyon analizi yapılmıştır. Verileri çoklu regresyon analizine hazır hale getirmek amacıyla çok yönlü uç değerler, Mahalonobis uzaklık testiyle incelenmiştir. Ki-kare analizinde. 001'den küçük olan 7 veri analiz dışında bırakılarak çok değişkenli normallik varsayımı karşılanmaya çalışılmıştır. Regresyon analizinde bağımsız değişkenler arasında çoklu bağıntı problemi olup olmadığı VIF ve tolerans değerleriyle incelenmiştir. Analiz sonucunda VIF ve tolerans değerlerinin istenen koşulları sağladığı görülmüştür. Bağımsız değişkenlere ilişkin VIF ve tolerans değerleri Tablo 1'de verilmektedir.

Tablo 1. Bağımsız değişkenlerin tolerans ve vıf değerleri

\begin{tabular}{lcc}
\hline Değişkenler & Tolerans & VIF \\
\hline Duygusal Zekâ & .87 & 1.14 \\
Pozitif İş-Aile yayılımı & .80 & 1.25 \\
Negatif İş-Aile yayılımı & .79 & 1.28 \\
Pozitif Aile-İş yayılımı & .78 & 1.27 \\
Negatif Aile-İş yayılımı & .72 & 1.38 \\
\hline
\end{tabular}

\section{BULGULAR}

Araştırma verilerinin analiz edilmesi sonucu elde edilen bulgular tablolar halinde sunulmuştur. Tablo 2'de katılımcıların örgütsel vatandaşlık. duygusal zekâ ve iş-aile yayılımı düzeyleri yer almaktadır.

Tablo 2. Katılımcıların örgütsel vatandaşlık. duygusal zekâ ve iş-aile yayılımı düzeyleri

\begin{tabular}{lccccc}
\hline Değişkenler & $n$ & $\overline{\mathrm{x}}$ & $S$ & Çarpıklık & Basıklık \\
\hline 1. Örgütsel Vatandaşlık & 200 & 5.08 & .45 & -.346 & -.121 \\
2. Duygusal Zekâ & 200 & 3.88 & .45 & -.343 & -.381 \\
3. Pozitif İş-Aile yayılımı & 200 & 4.38 & .71 & -1.17 & .845 \\
4. Negatif İş-Aile yayılımı & 200 & 2.83 & 1.24 & .285 & -1.045 \\
5. Pozitif Aile-İş yayılımı & 200 & 3.48 & 1.13 & -.585 & -.566 \\
6. Negatif Aile-İş yayılımı & 200 & 3.93 & .97 & -.918 & .656 \\
\hline
\end{tabular}


Tablo 2 incelendiğinde katılımcıların örgütsel vatandaşlık $(\bar{X}=96.39)$ ve duygusal zekâ $(\bar{X}=$ 158.75) düzeylerinin yüksek olduğu görülmektedir. Bununla birlikte katılımcıların iş-aile yayılımı bakımından pozitif aile-iş yayılımı bakımından negatif algının daha yüksek olduğu görülmektedir. Standart sapma değerlerine göre ise en homojen dağılımın pozitif iş-aile yayılımında $(S=.71)$. en heterojen dağılımın ise duygusal zekâ algısında $(S=18.41)$ gerçekleştiği görülmektedir. Tabachnick ve Fidell (2013) çarpıklık ve basıklık değerlerinin +1.5 ile -1.5 arasında olması halinde verilerin normal dağıldığını savunmuşlardır. Bu çalışmada kullanılan ölçeklerin ve boyutlarının çarpıklık ve basıklık değerleri +1.5 ile -1.5 arasındadır. $\mathrm{Bu}$ yüzden çalışmada parametrik testler kullanılmıştır.

Katılımcların örgütsel vatandaşlık davranışı duygusal zekâ ve iş-aile yayılımı düzeylerinin arasındaki ilişkiler Tablo 3'te sunulmuştur.

Tablo 3. Örgütsel Vatandaşlık Davranışı Duygusal Zekâ ve İş-Aile Yayılımları Arasındaki İlişkiler

\begin{tabular}{lcccccc}
\hline Değişkenler & $\mathbf{1}$ & $\mathbf{2}$ & $\mathbf{3}$ & $\mathbf{4}$ & $\mathbf{5}$ & $\mathbf{6}$ \\
\hline 1. Örgütsel Vatandaşlık & 1.00 & $.31^{* *}$ & $.20^{* *}$ & $-.19^{* *}$ & $.18^{* *}$ & $-.17^{* *}$ \\
2. Duygusal Zekâ & & 1.00 & $.12^{* *}$ & $-.11^{* *}$ & $.19^{* *}$ & $-.25^{* *}$ \\
3. Pozitif İş-Aile yayılımı & & & 1.00 & $-.02^{* *}$ & $.41^{* *}$ & $.14^{* *}$ \\
4. Negatif İş-Aile yayılımı & & & 1.00 & $.01^{* *}$ & $.45^{* *}$ \\
5. Pozitif Aile-İş yayılımı & & & & 1.00 & $.04^{* *}$ \\
6. Negatif Aile-İş yayılımı & & & & & & 1.00 \\
\hline
\end{tabular}

** $p<.01$

Tablo 3 incelendiğinde örgütsel vatandaşlık davranışı ile duygusal zekânın alt boyutlarından iyimserlik ile düşük düzeyde ve olumlu ilişkili olduğu görülmektedir ( $r=.31 . p<.01)$. Örgütsel vatandaşlık davranışı ile duyguların değerlendirilmesi alt boyutu arasında düşük düzeyde ve olumlu ilişki bulunmuştur $(\mathrm{r}=.20 . \mathrm{p}<.01)$. Benzer şekilde örgütsel vatandaşlık ile pozitif aile-iş yaşamı arasında olumlu ilişki bulunmuştur $(\mathrm{r}=.18 . \mathrm{p}<.01)$. Bununla birlikte duygusal zekâ ile negatif iş-aile yayılımı $(r=-.11 . p<.01)$ ve negatif aile-iş yayılımı $(r=-.25 . p<.01)$ düşük düzeyde ve negatif ilişkilidir. Tabloya göre duygusal zekâ ile pozitif iş-aile yayılımı $(r=.12 . p<.01)$ ve pozitif aile-iş yayılımı ( $\mathrm{r}=.19 . \mathrm{p}<.01)$ arasında düşük düzeyde olumlu ilişki bulunmuştur.

Katılımcların örgütsel vatandaşlık duygusal zekâ ve iş-aile yayılımı düzeylerinin cinsiyet değişkenine göre farklılığı için yapılan t-testi sonuçları Tablo 4'te verilmektedir. 
Tablo 4. Örgütsel vatandaşlık, Duygusal Zekâ ve Isş-Aile yayılımı Düzeylerinin Cinsiyete Göre t-Testi Sonuçları

\begin{tabular}{|c|c|c|c|c|c|c|c|}
\hline \multirow[t]{2}{*}{ Değişkenler } & \multicolumn{2}{|c|}{$\begin{array}{l}\text { Kadın } \\
(n=94)\end{array}$} & \multicolumn{2}{|c|}{$\begin{array}{l}\text { Erkek } \\
(n=106)\end{array}$} & \multirow[t]{2}{*}{$t$} & \multirow[t]{2}{*}{$s d$} & \multirow[t]{2}{*}{$P$} \\
\hline & $\bar{X}$ & $S$ & $\bar{X}$ & $S$ & & & \\
\hline 1. Örgütsel vatandaşlık & 5.07 & .46 & 5.09 & .45 & .27 & 198 & .79 \\
\hline 2. Duygusal zekâ & 3.98 & .44 & 3.78 & .44 & -3.21 & 198 & .00 \\
\hline 3. Pozitif aile-iş yayılımı & 4.41 & .76 & 4.35 & .66 & -.58 & 198 & .56 \\
\hline 4. Negatif aile-iş yayılımı & 3.02 & 1.27 & 2.66 & 1.18 & -2.13 & 198 & .03 \\
\hline 5. Negatif iş-aile yayılımı & 3.56 & 1.16 & 3.41 & 1.10 & -.92 & 198 & .35 \\
\hline 6. Pozitif iss-aile yayılımı & 4.04 & .98 & 3.82 & .95 & -1.16 & 198 & .11 \\
\hline
\end{tabular}

Tablo 4 incelendiğinde duygusal zekâ ve negatif iş-aile yayılımı değişkenlerine göre cinsiyet açısından anlamlı bir fark olduğu görülmektedir. Buna göre kadın katılımcıların duygusal zekâ ortalamalarının $(\bar{x}=3.98)$ erkeklere göre $(\bar{x}=3.78)$ daha yüksek olduğu anlaşılmaktadır $(t=$ -3.21; $\mathrm{p}<.05)$. Bununla birlikte katılımcıların negatif iş-aile yayılımı algılarında kadınların $(\bar{x}$ =3.56) erkeklere göre $(\bar{x}=3.41)$ daha yüksek olduğu $(\mathrm{t}=-.92 ; \mathrm{p}<.05)$ görülmektedir. Katılımcıların pozitif aile-iş yayılımı negatif iş-aile yayılımı ve pozitif iş-aile yayılımı algıları açısından cinsiyete göre anlamlı bir farklılık oluşmamakla birlikte kadınların daha yüksek ortalamalara sahip oldukları görülmektedir. Son olarak kadın ve erkek katılımcıların duygusal zekâ değişkeninde birbirlerine en yakın algılara sahip oldukları $(S=.44)$ ve negatif iş-aile yayılımı açısından farklı görüşlerin ortaya çıktığı $(S=.1 .27 ; S=1.18)$ görülmektedir.

Tablo 5'te iş-aile yayılımı ve duygusal zekânın aile-iş yayılımının örgütsel vatandaşlık üzerindeki etkisine ilişkin çoklu doğrusal regresyon analizi sonuçları verilmiştir.

Tablo 5. İş-Aile yayılımı ve Duygusal Zekânın Örgütsel Vatandaşlı̆̆ı Yordamasına İlişkin Regresyon Sonuçları

\begin{tabular}{llllll}
\hline Değişkenler & B & $\begin{array}{l}\text { Standart } \\
\text { Hata }\end{array}$ & $\beta$ & $\mathbf{T}$ & $\mathbf{p}$ \\
\hline Sabit & 76.85 & 6.37 & & 12.05 & .00 \\
\hline Pozitif aile-iş & 1.11 & .94 & .09 & 1.18 & .24 \\
Negatif aile-iş & -.66 & .56 & -.09 & -1.16 & .24
\end{tabular}




\begin{tabular}{lccccc} 
Negatif iş-aile & -1.02 & .59 & -.13 & -1.73 & .08 \\
Pozitif iş-aile & 1.36 & .68 & .15 & 1.98 & .04 \\
Duygusal zekâ & .09 & .03 & .19 & 2.70 & .01 \\
\hline
\end{tabular}

$\mathrm{R}=.37 . \mathrm{R}^{2}=.14 . \mathrm{F}=6.226^{*} \mathrm{p}<.05$.

Tablo 5 incelendiğinde iş-aile yayılımının örgütsel vatandaşlığı anlamlı düzeyde yordadığı $(\mathrm{R}=.37$. $\mathrm{R} 2=.14 . \mathrm{F}=6.226 . \mathrm{p}<.05)$ ve örgütsel vatandaşlık davranışına ilişkin toplam varyansın \%14'ünü açıladığı görülmektedir. İlgili $\beta$ değerleri incelendiğinde en güçlü yordayıcı değişkenlerin duygusal zekâ ( $\beta=.19)$ pozitif iş-aile yayılımı $(\beta=.15)$ olduğu görülmektedir. Negatif aile-iş ve negatif iş-aile yayılımı örgütsel vatandaşlığı olumsuz etkilemekle birlikte yordayıcılığı anlamlı değildir.

\section{SONUÇ, TARTIŞMA VE ÖNERİLER}

Mevcut çalışmada özel bir çağrı merkezinde görev yapan çalışanların örgütsel vatandaşlık davranışlarının açıklanması amacıyla duygusal zekâ ve iş-aile yayılımları incelenmiştir. Araştırma kapsamında katılımcıların örgütsel vatandaşlık, duygusal zekâ ve iş-aile yayılımı düzeylerinin incelenmesi sonucunda katılımcıların örgütsel vatandaşlık ve duygusal zekâ düzeylerinin yüksek olduğu ( $\overline{\mathrm{X}}=5.08 ; \overline{\mathrm{X}}=3.88)$ görülmektedir. Özellikle iş-ile ilişkisi konusunda öncü çalışmalar yapan Pleck'e göre (1977) çalışanların olumlu duygu ve durumları işten eve olumsuz duygu ve durumları evden işe götürme ihtimalleri daha yüksektir. Bu durumu doğrular nitelikte mevcut çalışmada katılımcıların pozitif iş aile yayımlarının pozitif aile iş yayımlarına göre daha yüksek ve negatif aile-iş yayılımları negatif iş-aile yayılımına göre daha yüksektir. Başka bir anlatımla çalışanlar işteki olumlu durumları eve iletme ve evdeki olumsuz durumları işe iletme eğilimindedirler. Söz konusu durumun ampirik olarak desteklenmesi Türk kültüründe çalışanların iş-aile dengesinin anlaşılması ve bireylerin mutluluğu veya işyerinde verim gibi konuların çalışılmasında önemli katkı sağlayabilir.

Araştırmanın ikinci alt problemine göre örgütsel vatandaşlık, duygusal zekâ ve iş-aile yayılımlarının ilişkisi incelenmiştir. Çalışma sonuçlarına göre örgütsel vatandaşlık ile duygusal zekâ arasında zayıf düzeyde olumlu ilişki bulunmuştur. Duygusal zekâ ile örgütsel vatandaşlık arasındaki ilişkinin ele alındığı birçok araştırma mevcuttur. Buna göre örgütsel vatandaşlık ile duygusal zekâ arasında orta düzeyde olumlu ilişki görülen (Çarıkçı, Kanten ve Kanten, 2010; Çüçen, 2014 Özyer ve Alici, 2015; Yancı ve Çiçek-Sağlam, 2014) ve ilişki bulunmayan (Gürbüz ve Yüksel, 2008) çalışmalar mevcuttur. Mevcut çalışmada elde edilen sonuçlara göre duygusal zekanın örgütsel davranış ile ilişkili bulunması literatür ile uyumludur.

Çalışmada katılımcıların cinsiyetlerine göre duygusal zekâ düzeyleri kadınlar lehine yüksek bulunmuştur. Literatürde kadınların duygusal zekâsının erkeklere göre daha yüksek olduğunu gösteren çalışmalar yoğunluktadır (Erdoğdu, 2008; Katyal ve Awasthi. 2005; Nasir ve Masrur, 2010; Özdemir ve Özdemir, 2007). Bununla birlikte kadın ve erkeklerin duygusal zekâ düzeylerinde farklılık bulunmayan araştırmalar mevcuttur (Çimli ve Çelik, 2019; Meshkat ve Nejati. 2017). Literatürde duygusal zekanın genellikle kadın katılımcılar lehine anlamlı çıkması mevcut çalışmanın sonuçları ile de uyumludur. 
Mevcut çalışmada kadın ve erkek katılımcıların negatif iş-aile yayılımları arasında anlamlı farklılıklar bulunmuştur. Benzer şekilde kadın katılımcıların daha yüksek düzeyde negatif işaile yayılımı yaşadığının belirtildiği çalışmalar mevcuttur (Birsbois, 2002). Kadın katılımcıların iş dolayısıyla edindikleri negatif yayılımın ailelerinde daha fazla algılanması erkeklere göre evdeki sorumluluklarının daha fazla olması ile açıklanabilir. İş-aile yayılımı konusunda Türkçe literatürdeki az sayıdaki çalışma arasında yer alan Polatcı ve Keser (2017) negatif iş-aile yayılımında kadınların daha yüksek ortalamalara sahip olduğunu ve diğer yayılım boyutlarında cinsiyete göre farklılık bulunmadığını ifade etmiştir. Başka bir çalışmada negatif iş-aile ve pozitif aile-iş yayılmasında kadınlar lehine anlamlı farklılık bulunmuştur (Grzywacz. Almeida ve McDonald, 2002).

Çalışmada örgütsel vatandaşlığın iş-aile yayılımı ve aile-iş yayılımının negatif ve pozitif durumları ile duygusal zekâ tarafından yordanma durumu incelenmiştir. Araştırma bulgularına göre örgütsel vatandaşlık pozitif iş-aile yayılımı ve duygusal zekâ değişkenleri tarafından olumlu yordanmaktadır. Başka bir anlatımla bireylerin örgütsel vatandaşlık davranışları üzerinde olumlu iş-aile yayılımlarının olması ve duygusal zekâ düzeyleri etkilidir. Literatürde duygusal zekânın örgütsel vatandaşlık üzerindeki olumlu etkilerini ifade eden birçok araştırma mevcuttur (Çarıkçı, Kanten ve Kanten, 2010; Gürbüz ve Yüksel, 2008; Örücü ve İzci, 2015; Tokmak, Ylldız ve Turgut, 2013). Ancak aile ve iş ilişkisinin örgütsel vatandaşlığa etkisini inceleyen çalışmalar sınırlıdır.

Çalışma kapsamında elde edilen sonuçlar örgütsel vatandaşlı̆̆ın bireyin duygusal zekâsı ve aile-iş hayatı dengesi ile olan ilişkisinin açıklamasına sağladığı katkı açısından önemlidir. Buna göre bireylerin örgütte verimli çalışma ortamına katkı sağlayabilmelerinde duygusal zekânın önemi ve aile-iş dengesinin etkisi üzerinde durulması gereken dinamiklerdir. Mevcut çalışmada elde edilen sonuçların sözkonusu bireysel ve ailevi değişkenlerin örgütsel değişkenler üzerinde rolünün vurgulanması bakımından önemli olduğu görülmektedir.

Başka çalışmalarda katılımcıların aile hayatları ve iş-aile dengelerinin daha iyi anlaşılabilmesi bakımından aile hayatlarına ilişkin bazı değişkenler eklenebilir. Çalışanların duygusal zekâ düzeylerinin örgütsel vatandaşlık davranışları üzerindeki etkisi dikkate alındığında işe alım ve mesleki gelişim süreçlerinde duygusal gelişimin dikkate alınması sağlanabilir. Çalışanların işten aileye veya aileden işe getirdikleri olumlu veya olumsuz özelliklerin belirli aralıklarla incelenmesi işyerinde verimi ve çalışanların kendileri ve işlerine yönelik olumlu algılarının desteklenmesini sağlayabilir.

\section{KAYNAKÇA}

Akın, M. (2004). İşletmelerde duygusal zekânın üst kademe yöneticiler ile astları arasındaki çatışmalar üzerindeki etkileri. Yayımlanmamış doktora tezi, Anadolu Üniversitesi, Sosyal Bilimler Enstitüsü, Eskişehir.

Akintayo, D. I. (2010). Influence of emotional intelligence on work-family role conflict management and reduction in withdrawal intentions of workers in private organizations. The International Business \& Economics Research Journal, 9(12), 131-140. 
Arslan, G. S. (2019). Duygusal zekâ ve iş tatmini ilişkisi: Bir kamu kurumu örneği. Yayımlanmamış yüksek lisans tezi, Bolu Abant İzzet Baysal Üniversitesi, Sosyal Bilimler Enstitüsü, Bolu.

Bachman, J., Stein, S., Campbell, K. \& Sitarenios, G. (2000). Emotional intelligence in the collection of debt. International Journal of Selection and Assessment, 8(3), 176-182.

Baron, R. (1997). The emotional intelligence inventory (EQ-I): Technical manual. Toronto. Canada: Multi-Health Systems.

Barsade, S. G. (2002). The ripple effect: Emotional contagion in groups. Administrative Science Quarterly, 47(4), 644-675.

Bolino, M. C., Turnley, W. H., \& Niehoff, B. P. (2004). The other side of the story: Reexamining prevailing assumptions about organizational citizenship behavior. Human Resource Management Review, 14(2), 229-246.

Brisbois, R. M. (2002). A multidimensional assessment of work family spillover. Available from ProQuest Dissertations \& Theses Global. (304803108). 1 Ocak 2020 tarihinde https://www.proquest.com/docview/304803108?accountid=17384 adresinden alındı.

Carmeli, A. (2003). The relationship between emotional intelligence and work attitudes behavior and outcomes: An examination among senior managers. Journal of managerial Psychology, 18(8), 788-813.

Crouter, A. C. (1984). Spillover from family to work: The neglected side of the work-family interface. Human Relations, 37(6), 425-441.

Çarıkçı, İ., Kanten, S., \& Kanten, P. (2010). Kişilik, duygusal zekâ ve örgütsel vatandaşlık davranışları arasındaki ilişkileri belirlemeye yönelik bir araştırma. Süleyman Demirel Üniversitesi Sosyal Bilimler Enstitüsü Dergisi, (11), 41-65.

Çelik, M., \& Çıra, A. (2013). Örgütsel vatandaşlık davranışının iş performansı ve işten ayrılma niyeti üzerine etkisinde aşırı iş yükünün aracılık rolü. Ege Akademik Bakış, 13(1), 11-20.

Çimli, S., \& Çelik, M. (2019). Çalışanların duygusal zekâ düzeylerinin stresle başa çıkma tarzları üzerine etkisi. Türk Sosyal Bilimler Araştırmaları Dergisi, 4(1), 80-92.

Çüçen, M. (2014). Duygusal zekâ ile bütüncül performansin bir unsuru olarak örgütsel vatandaşlık davranışlar arasındaki ilişki Adnan Menderes Üniversitesi idari personeli üzerine bir uygulama. Yayımlanmamış yüksek lisans tezi, Adnan Menderes Üniversitesi, Aydın.

Delice, M. \& Günbeyi, M. (2013). Duygusal zekâ ve liderlik ilişkisinin incelenmesi: Polis teşkilatı örneği. Atatürk Üniversitesi İktisadi ve İdari Bilimler Dergisi, 27(1), 209-239.

Doğan, S. \& Demiral, Ö. (2007). Kurumların başarısında duygusal zekânın rolü ve önemi. Yönetim ve Ekonomi: Celal Bayar Üniversitesi İktisadi ve İdari Bilimler Fakültesi Dergisi, 14(1), 209-230.

Er. E., Akyol. B., \& Koşar, S. (2019). Örgütsel vatandaşlık konusunda yapılan lisansüstü tezlerin içerik analizi çalışması. 14. Uluslararası Ĕ̆itim Yönetimi Kongresi, Çeşme, İzmir.

Eymen, E. (2007). Duygusal zekâ. İzmir: Kalite Ofisi Yayınları. 
George, J. M. \& Bettenhausen, K. (1990). Understanding prosocial behavior sales performance and turnover: A grouplevel analysis in a service context. Journal of Applied Psychology, 75, 698-709.

Goleman, D. (1995). Duygusal zekâ neden IQ'dan daha önemlidir? (B. S. Yüksel. Çev.) İstanbul: Varlik.

Grzywacz, J. G., Almeida, D. M. \& McDonald, D. A. (2002). Work-family spillover and daily reports of work and family stress in the adult labor force. Family relations, 51(1), 28-36.

Gürbüz, S., \& Yüksel, M. (2008). Çalışma ortamında duygusal zekâ: İş performansı. iş tatmini. örgütsel vatandaşlık davranışı ve bazı demografik özelliklerle ilişkisi. Doğuş Üniversitesi Dergisi, 9(2), 174-190.

Hanson, G. C., Hammer. L. B., \& Colton. C. L. (2006). Development and validation of a multidimensional scale of perceived work-family positive spillover. Journal of Occupational Health Psychology, 11(3), 249-265.

İşmen, A. E. (2004). Duygusal zekâ ve aile işlevleri arasındaki ilişki. Balıkesir Üniversitesi Sosyal Bilimler Enstitüsü Dergisi, 7(11), 55-77.

Katyal, S., \& Awasthi. E. (2005). Gender differences in emotional intelligence among adolescents of Chandigarh. Journal of Human Ecology, 17(2), 153-155.

Kelloway, E. K., Loughlin. C., Barling. J., \& Nault, A. (2002). Self-Reported Counterproductive Behaviors and Organizational Citizenship Behaviors: Separate but Related Constructs. International Journal of Selection and Assessment. 10(1-2), March/June, 143-151.

Kirchmeyer, C. (1993). Nonwork-to-work spillover: A more balanced view of the experiences and coping of professional women and men. Sex Roles, 28(9-10), 531-552.

Koşar, D. \& Yalçınkaya, M. (2013). Öğretmenlerin örgütsel vatandaşlık davranışlarının yordayıcıları olarak örgüt kültürü ve örgütsel güven. Kuram ve Uygulamada Eğitim Yönetimi, 4(4), 603-627.

Lusch, R. F. \& Serpkenci, R. R. (1990). Personal differences, job tension, job outcomes, and store performance: A study of retail store managers. Journal of Marketing, 54(1), 85-101.

Mayer, J. D., Salovey, P., \& Caruso, D. R. (2000). Models of emotional intelligence. In R. J. Sternberg (Ed.), Handbook of intelligence (pp. 396-420). New York, NY: Cambridge University Press.

Meshkat, M. \& Nejati, R. (2017). Does emotional intelligence depend on gender? A study on undergraduate English majors of three Iranian universities. SAGE Open, 7(3), 1-8.

Nikolaou, I. \& Tsaousis, I. (2002). Emotional intelligence in the workplace: Exploring its effects on occupational stress and organizational commitment. The International Journal of Organizational Analysis, 10(4), 327-342.

Organ, D. W. (1988). Organizational citizenship behavior: The Good Soldier Syndrome. Lexington. MA: Lexington Books. 
Örücü, E. \& İzci, Ç. (2015). Otel çalışanları açısından duygusal zekânın örgütsel vatandaşlık davranışı üzerindeki etkisi. Erciyes Üniversitesi İktisadi ve İdari Bilimler Fakültesi Dergisi, (45), 31-47.

Özabacı, N. (2006). Emotional intelligence and family environment. Sosyal Bilimler Dergisi, 16, 169-175.

Özdemir, A. Y., \& Özdemir, A. (2007). Duygusal zekâ ve çatışma yönetimi stratejileri arasındaki ilişkilerin incelenmesi: Üniversitede çalışan akademik ve idari personel üzerine uygulama. Selçuk Üniversitesi Sosyal Bilimler Enstitüsü Dergisi, (18), 393-410.

Pleck, J. H. (1977). The work-family system. Social Problems, 24, 417-427.

Podsakoff, P. M., Ahearne, M. \& MacKenzie, S. B. (1997). Organizational citizenship behavior and the quantity and quality of work group performance. Journal of Applied Psychology, 82(2), 262-270.

Polatc1, S. (2011). Psikolojik sermayenin performans üzerindeki etkisinde iş aile yayılımı ve psikolojik iyi oluşun rolü. Yayımlanmamış doktora tezi, Erciyes Üniversitesi, Sosyal Bilimler Enstitüsü, Kayseri.

Polatcı, S. \& Keser, A. (2017). İş aile yayılımının bireyin iş ve yaşam tatmini üzerindeki etkilerine yönelik bir araştırma. Ankara Üniversitesi SBF Dergisi, 72(2), 401-421.

Sezgin, F. (2005). Örgütsel vatandaşlık davranışları: kavramsal bir çözümleme ve okul açısından bazı çıkarımlar. Gazi Ĕ̆itim Fakültesi Dergisi, 25(1), 317-339.

Sy., T., Tram, S., \& O'Hara, L. A. (2006). Relation of employee and manager emotional intelligence to job satisfaction and performance. Journal of Vocational Behavior, 68(3), 461-473.

Tabachnick, G. B. \& Fidell, S. L. (2013). Using multi variate statistics. (6th. Ed.) Pearson Publishing. USA: Boston.

Tokmak, İ., Yıldız, E., \& Turgut, H. (2013). Duygusal zekânın örgütsel vatandaşlık davranışına etkisi: İş tatmininin aracılık rolü. Çă̆ Üniversitesi Sosyal Bilimler Dergisi, 10(1), 96-114.

Yancı, F., \& Sağlam, A. Ç. (2014). Ortaöğretim okulu öğretmenlerinin duygusal zekâları ile örgütsel vatandaşlık davranışları arasındaki ilişki. Uşak Üniversitesi Sosyal Bilimler Dergisi, 7(1), 298-313.

Yeşilyaprak, B. (2001). Duygusal zekâ ve eğitim açısından doğurguları. Gazi Üniversitesi Eğitim Yönetimi Dergisi, 25, 139-141.

Yıldırım, Ç. \& Kara, S. B. K. (2018). Öğretmenlerin örgütsel vatandaşlık davranışlarının yordayıcısı olarak örgütsel sosyalleşme. Muğla Sıtkı Koçman Üniversitesi Eğitim Fakültesi Dergisi, 5(2), 43-54.

Williams, L. J., \& Anderson, S. E. (1991). Job satisfaction and organizational commitment as predictors of organizational citizenship and in-role behaviors. Journal of Management, 17(3), 601-617. 